\title{
Histochemical Studies of Hydroxysteroid Dehydrogenases in the Busulphan-Treated Rat Testis
}

\author{
Masaharu TANAKA and Kazuo IsHIDA \\ Department of Animal Husbandry, Faculty of Agriculture, \\ Niigata University, Niigata-shi 950-21
}

(Accepted for publication July 6, 1987)

\begin{abstract}
Summary. Activities of $\Delta^{5}-3 \beta$-hydroxysteroid dehydrogenase $\left(\Delta^{5}-3 \beta\right.$-HSD), $20 \beta$-HSD and $17 \beta$-HSD in Sertoli and Leydig cells of $0-50$ days old infant rats born of busulphantreated dams were histochemically quantitated using dehydroepiandrosterone (DHA), pregnenolone, $17 \alpha$-hydroxypregnenolone, $20 \beta$-hydroxyprogesterone, testosterone and estradiol-17 $\beta$ as the substrates. All the HSD activities were detectable in Sertoli cells of 20-50 days old infant animals born of both the control and the busulphan-treated dams. At the age of 40 days, activities of individual HSD in the cells were higher in infants born of the treated dams than in animals born of the control ones. When DHA and pregnenolone were used as the substrates, Leydig cells of infant rats born of the treated dams exhibited a higher $\Delta^{5}-3 \beta$-HSD activity as did the cells of control infant animals. Compared to control infants, however, the other HSD activities were consistently lower in Leydig cells of infant rats born of the treated dams. KEY WORDS; BUSULPHAN, HYDROXYSTEROID DEHYDROGENASE, RAT TESTIS.
\end{abstract}

Jpn J Anim Reprod 33, 128-133, 1987

\section{ブスルファンにより生殖細胞を退行させたラット精巣における ヒドロキシステロイド脱水素酵素の組織化学的研究}

田中 雅治・石田 一夫

新潟大学農学部 $950-21$ 新潟市五十嵐二の町 8050

\footnotetext{
哺乳動物の精巣におけるアンドロジェン生合成の主要 部位がライディヒ細胞であることは，多くの研究者によ って調べられて打り，精_上迕はライディヒ細胞からのス テロイドホルモン分泌の影響を受けて生殖細胞の增殖と 分化を行うといわれている ( - oom and Fawcett, 1983)。 一方，七ルトリ細胞の分離・培篦によって生化学的に, セルトリ細胞にもステロイド代謝能の存在が報告されて いる (Dorrington et al., 1976. 1978; Tence and Drosdowsky, 1976; Tcholakian and Steinberger, 1978: Wiebe, 1978; Wiebe and Tilbe, 1979)。最近, 因. 石田（1987）はラットのセルトリ細胞について各種の, ドロキシステロイド脱水素醭素 (HSD) 活性を検出し,
}

セルトリ細胞にステロイド代謝能が存在することを組織 化学的観点からも示唆した。しかしながら，セルトリ細 胞におけるステロイド代謝の生理的役割については明ら かでない。

ブスルファン（ミレラン）は活性のアルキル化剂で, 主として慢性骨髄性白血病の治療に用いられているが, この薬剂を成熟ラットに投与すると生殖細胞が退行する といわれて打り (Bollag，1953)，また，妊娠ラットに投 与すると出生仔でも生殖細胞が欠如することが知られて いる(Hemsworth and Jackson, 1962，1963)。

本研究は, 生殖細胞が欠如した際のセルトリ細胞とラ イディヒ細胞に打けるステロイド代謝の変化を調べる目 
的で，ブスルファンを投与した妊娠ラットから生まれた 個体の精巣と無処置娃娠ラットから生まれた個体の精巣 のセルトリ細胞とライディヒ細胞における各種 HSD 活 性を組織化学的に検出し, 両者の精巣の間で比較したも のである。

\section{材料と方法}

供試動物として，正常な性周期を有するウイスター系 ラットの雌 24 匹使用した。飼育は $24^{\circ} \mathrm{C}$ に調節したコ イトトロン $(\mathrm{EA}-8 \mathrm{HW})$ 内で行い, 点灯は午前 4 時から 午後 6 時までの14時間とした。これらのラットは発情前 期に同系統の雄と一晚同居させ, 翌朝, 胵垢内の精子を 確認して，その日を妊娠 1 日とした。これらの妊娠ラッ トの半数にアラビアゴムに眯濁させたブスルファン（マ ブリン散, 武田薬品工業) を体重 $100 \mathrm{~g}$ あたり $1 \mathrm{mg} の$ 割合で妊娠13日に腹腔内注射した (Hemsworth and Jackson, 1962, 1963)。出生仔の精巣は出生直後から生後 50日までの間，10日間隔で採取した。一側の精巣は，組 織学的観察のためにブアン液で固定し, 常法に従ってへ マトキシリン・エオシン染色標本を作製した。他側の精 巣は, 各種 HSD 活性検出のためにドライアイス・アセ トンで涷結し，クリオスタットで $15 \mu \mathrm{m}$ に薄切した。

HSD 活性の検出は Levy et al. (1959) の方法に準じ て行った。基質液の組成は，ステロイド基質 $0.4 \mathrm{mg}(2$ $\mathrm{ml}$ のアセトンに溶解), プロピレングリコール $1 \mathrm{ml}$, 補 酵素 $4.8 \mathrm{mg}(1.6 \mathrm{ml}$ の蒸留水に溶解), ニトロ $\mathrm{BT} 2.0$ $\mathrm{mg}(2 \mathrm{ml}$ の蒸留水に溶解), ニコチンアミド $2.3 \mathrm{mg}$ $(1.4 \mathrm{ml}$ の蒸留水に溶解) および $0.1 \mathrm{M}$ リン酸綏衝液 （pH 7.4） $8 \mathrm{ml}$ である。使用した基質は，デヒドロエピ

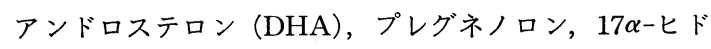

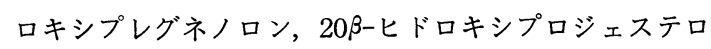
ン，テストステロンおよびエストラジオール $17 \beta$ であ る。な抢, 補酵素にはNADを用いた。これらの対照と して，基質を含まない液を使用した。切片の基質液への

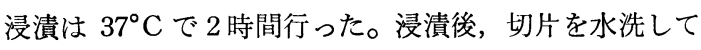
$10 \%$ ホルマリン液で固定し, グリセリンゼリーで封入し た。

\section{結 果}

組織学的観察 無処置妊娠ラットから生まれた個体の 精巣は, 出生直後では, セルトリ細胞は円柱状で棈円形 の核を有して打り，精細管壁の内側に一層をなして並ん でいた。セルトリ細胞に介在して, 幼若な大型の精祖細
胞がみられた。ライディヒ細胞は小型で，円形の核を有 しており, 線維芽細胞とともに間質に散在していた。生 後10日では, セルトリ細胞は伸長し, 精祖細胞は大部分 が成熟して有糸分裂像もみられた。生後20日では，セル トリ細胞は輪郭が不明瞭となり, 精母細胞が出現した。 一部の精細管には管腔がみられた。生後30日では, 精上 皮に精娘細胞が観察され,一部には精子細胞もみられた。 生後40日では, 精子のみられる精細管も散見された。生 後50日では, 多くの精細管に精子が認められた。ライデ 亿細胞は精巣の発育とともに大型化した (Fig. 1)。

ブスルファン投与娃娠ラットから生まれた個体の精巣 は, 出生直後では, 無処置のものと同様, 基底膜に沿っ て円柱状のセルトリ細胞がみられたが，生殖細胞はブス ルファン投与の影響を受けてほとんど欠如していた。生 後10日と20日では, セルトリ細胞は伸長し，その先端は 柔毛状を呈していた。細胞の輪郭は無処置のものに比へ て明瞭であった。生後30日と40日では，ほとんどの精細 管に管腔が出現した。生後50日では, ごく一部の精細管 に精子形成がみられたが，多くの精細管ではセルトリ細 胞だけが観察された。精巣の発育期間をとおして, 精細 管の発達はきわめて悪かった。ライディヒ細胞の形態は 無処置のものと同様であった (Fig. 2)。

組織化学的観察 精巣の HSD 活性は, セルトリ細胞 とライディヒ細胞の細胞質にジホルマザン顆粒として証 明された（Figs. 3〜6)。な打，基質を含まない液に切片 を浸漬した場合には，ジホルマザン顆粒はまったく現わ れなかった (Fig. 3b)。

1. セルトリ細胞

無処置打よびブスルファン投与妊娠ラットから生まれ た個体の精巣のセルトリ細胞について, 各種の HSD 活 性を調べたところ, Table 1 に示したような成績が得ら れた。

無処置妊娠ラットから生まれた個体のセルトリ細胞に おける HSD 活性は，いずれの基質を用いた場合にも生 後20日から出現し, 生後30日から強くなった（Fig. 3a)。 ブスルファン投与妊娠ラットから生まれた個体のセルト リ細胞における HSD 活性も無処置のものと同様, 生後 20日から出現し, 生後30日から強くなった。とくに, 生 後40日以降は無処置のものより強い活性を示した（Fig. 4)。

\section{2. ライディヒ細胞}

無処置およびブスルファン投与娃娠ラットから生まれ た個体の精巣のライディヒ細胞について, 各種の HSD 活性を調べたところ, Table 2 に示したような成績が得 


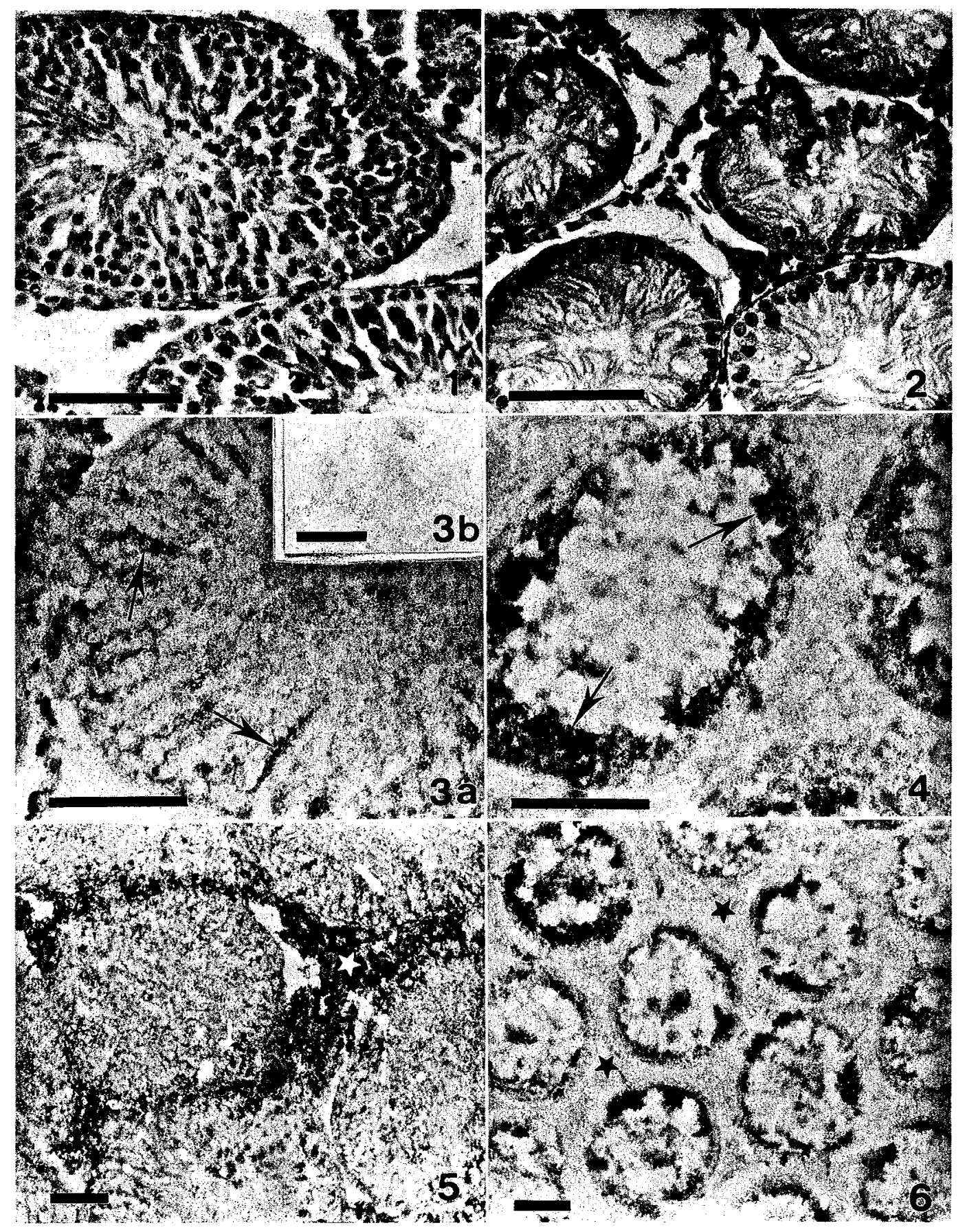


Table 1. Hydroxysteroid dehydrogenase activities of Sertoli cells in rat testes

\begin{tabular}{|c|c|c|c|c|c|c|c|c|}
\hline \multirow{2}{*}{ Enzymes } & \multirow{2}{*}{ Substrates } & \multirow{2}{*}{ Treatments to dams } & \multicolumn{6}{|c|}{ Days after birth } \\
\hline & & & 0 & 10 & 20 & 30 & 40 & 50 \\
\hline \multirow{6}{*}{$\Delta^{5}-3 \beta-\mathrm{HSD}$} & \multirow{2}{*}{$\mathrm{DHA}$} & Non-treated & - & - & \pm & + & + & H \\
\hline & & Busulphan-injected & - & - & \pm & + & $H$ & H \\
\hline & \multirow{2}{*}{ Pregnenolone } & Non-treated & - & - & $\dot{T}$ & + & $+t$ & + \\
\hline & & Busulphan-injected & - & - & \pm & + & $H$ & H \\
\hline & \multirow{2}{*}{$\begin{array}{l}17 \alpha \text {-hydroxy- } \\
\text { pregnenolone }\end{array}$} & Non-treated & - & - & + & + & + & + \\
\hline & & Busulphan-injected & - & - & \pm & + & H & H \\
\hline \multirow{2}{*}{$20 \beta$-HSD } & \multirow{2}{*}{$\begin{array}{l}20 \beta \text {-hydroxy- } \\
\text { progesterone }\end{array}$} & Non-treated & - & - & + & + & + & + \\
\hline & & Busulphan-injected & - & - & \pm & + & $H$ & m \\
\hline \multirow{4}{*}{$17 \beta$-HSD } & \multirow{2}{*}{ Testosterone } & Non-treated & - & - & \pm & + & + & + \\
\hline & & Busulphan-injected & - & - & \pm & + & t. & H \\
\hline & \multirow{2}{*}{ Estradiol-17 $\beta$} & Non-treated & - & - & \pm & + & + & + \\
\hline & & Busulphan-injected & - & - & \pm & + & W & H \\
\hline
\end{tabular}

Intensity of the reaction is graded from -, no reaction, to $\mathrm{H}$, the maximum reaction.

Table 2. Hydroxysteroid dehydrogenase activities of Leydig cells in rat testes

\begin{tabular}{|c|c|c|c|c|c|c|c|c|}
\hline \multirow{2}{*}{ Enzymes } & \multirow{2}{*}{ Substrates } & \multirow{2}{*}{ Treatments to dams } & \multicolumn{6}{|c|}{ Days after birth } \\
\hline & & & 0 & 10 & 20 & 30 & 40 & 50 \\
\hline \multirow{6}{*}{$\Delta^{5}-3 \beta-\mathrm{HSD}$} & \multirow{2}{*}{ DHA } & Non-treated & m & 世 & 世 & m & H & \# \\
\hline & & Busulphan-injected & H & H & H & 世 & H & H \\
\hline & \multirow{2}{*}{ Pregnenolone } & Non-treated & $H$ & $H$ & $H$ & H & $H$ & $H$ \\
\hline & & Busulphan-in jected & $H$ & $H$ & H & $H$ & $H$ & H \\
\hline & \multirow{2}{*}{$\begin{array}{l}17 \alpha \text {-hydroxy- } \\
\text { pregnenolone }\end{array}$} & Non-treated & - & - & H & $H$ & $H$ & H \\
\hline & & Busulphan-injected & - & - & - & + & $t$ & + \\
\hline \multirow{2}{*}{$20 \beta$-HSD } & \multirow{2}{*}{$\begin{array}{l}20 \beta \text {-hydroxy- } \\
\text { progesterone }\end{array}$} & Non-treated & - & - & $H$ & $H$ & $H$ & H \\
\hline & & Busulphan-injected & - & - & - & + & + & + \\
\hline \multirow{4}{*}{$17 \beta$-HSD } & \multirow{2}{*}{ Testos terone } & Non-treated & $H$ & $H$ & $H$ & H & $H$ & H \\
\hline & & Busulphan-injected & - & - & - & + & + & + \\
\hline & \multirow{2}{*}{ Estradiol-17 $\beta$} & Non-treated & $H$ & $H$ & $H$ & H & H & $H$ \\
\hline & & Busulphan-injected & - & - & - & + & + & + \\
\hline
\end{tabular}

Intensity of the reaction is graded from -, no reaction, to $\mathrm{H}$, the maximum reaction.

\section{Explanation of Figures (Scales indicate $8 \mu \mathrm{m}$ )}

Fig. 1. Seminiferous tubules in a testis of a 50-day-old rat born of a non-treated dam. Hematoxylin and eosin stain. The testis exhibits full spermatogenesis. Fig. 2. Seminiferous tubules in a testis of a 50-day-old rat born of a busulphan-injected dam. Hematoxylin and eosin stain. Germinal epithelia are composed of only Sertoli cells. Fig. 3a. A seminiferous tubule in a testis of a 50-day-old rat born of a non-treated dam. Levy et al. method using pregnenolone as the substrate. A weak activity of HSD is seen in the cytoplasm of Sertoli cells (arrows). Fig. 3b. A seminiferous tubule in a testis of a 50-day-old rat born of a non-treated dam. Levy et al. method without the substrate. No activity of HSD is scen in the cytoplasm of Sertoli cells. Fig. 4. Seminiferous tubules in a testis of a 50-day-old rat born of a busulphan-injected dam. Levy et al. method using pregnenolone as the substrate. A strong activity of HSD is seen in the cytoplasm of Sertoli cells (arrows). Fig. 5. Interstitial tissue (star mark) in a testis of a 50-dayold rat born of a non-treated dam. Levy et al. method using testosterone as the substrate. A strong activity of HSD is seen in the cytoplasm of Leydig cells. Fig. 6. Interstitial tissue (star mark) in a testis of a 50-day-old rat born of a busulphan-injected dam. Levy et al. method using testosterone as the substrate. A very weak activity of HSD is seen in the cytoplasm of Leydig cells. 
られた。

無処置妊娠ラットから生まれた個体のライディヒ細胞 に扔ける HSD 活性は， DHA，プレグネノロン，テス トステロンおよびエストラジオール $17 \beta$ を基質に用いた 場合には出生時にすでに認められたが，17 $\alpha$-ヒドロキシ プレグネノロンと20ß-ヒドロキシプロジェステロンを基 質に用いた場合には生後20日から観察された (Fig. 5)。 ブスルファン投与妊娠ラットから生まれた個体のライデ ィヒ細胞における HSD 活性は, DHA とプレグネノロ ンを基質とした場合には，無処置のものと同様，出生時 にすでに認められたが，その他の基質を用いた場合には 生後30日から出現し, 無処置のものと比較して弱かった (Fig. 6)。各種 HSD の間では，酵素活性は DHA を基 質に用いた場合には強かったが，他の基質を用いた場合 には弱く, 活性の強さは生後50日まで変わらなかった。

\section{考察}

Tence and Drosdowsky (1976) は, 無処置およびブ スルファン投与娃娠ラットから生まれた個体の精細管を 分離・培養してセルトリ細胞のステロイド代謝産物を生 化学的に測定した。その結果, 無処置, ブスルファン投 与, いずれのラットのセルトリ細胞に打いても, プロジ

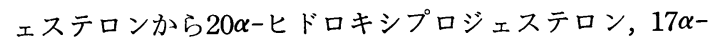
ヒドロキシプロジェステロン㧊よ゙゙アンドロステンジオ ンへの転換と, テストステロンからジヒドロテストステ ロン, アンドロステンジオンなどへの転換を認めて打 り，これらのステロイド代謝産物はブスルファン投与の ものが無処置のものより多いと述べている。この中で,

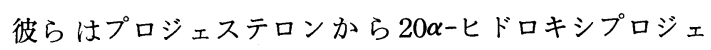
ステロンへの転換を述べているが，このことは，Wiebe (1978) や Tcholakian and Steinberger (1978) によって も調べられて打り,ラットのセルトリ細胞では $20 \alpha-H S D$ 活性の存在が示唆される。しかしながら, 田中と石田 (1987)は，ラットのセルトリ細胞のプロシェェステロン代 謝を組織化学的に調べたところ,この細胞には $20 \beta-H S D$

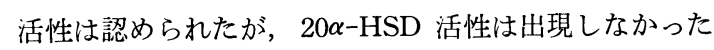
と報告した。本実験のラット精巣のセルトリ細胞では, いずれの出生仔に扔いても $\Delta^{5}-3 \beta-H S D, 17 \beta-H S D$ およ び 20 $\beta$-HSD の活性が観察され, その活性はブスルファ ン投与のものが無処置のものより高かった。このこと は, Tence and Drosdowsky（1976）がステロイド代謝 はブスルファン投与ラットのセルトリ細胞が無処置のも のより多いと報告していることを組織化学的観点から支 持するものである。電顕的には，セルトリ細胞は細胞基
底部に滑面小胞体が発達しているといわれて扔り，この 像はステロイドホルモンの分泌を示唆していると考えら れている (Bloom and Fawcett, 1983)。Aumüller et al. （1980）は精巣停留処置を施したラットで, 小家と石田 （1985）はブスルファンを投与した妊娠ラットから生ま れた個体でセルトリ細胞の微細構造を観察しておうり, 滑 面小胞体は無処置のものよりもよく発達していたと報告 している。このことから, 生殖細胞が欠如したラット精 巣のセルトリ細胞は無処置のものに比べてステロイドの 産生・代謝能が高進していることが推察される。

下垂体摘出 (Samuels and Helmreich, 1956; Niemi and Ikonen, 1962) やX線照射 (Schoen, 1964) によっ て生殖細胞を退行させたラット精巣のライディヒ細胞に おける HSD 活性については, 生化学的または組織化学 的に調べられている。すなわち，このようにして奏験的 に生殖細胞を退行させたラット精巣のライディヒ細胞で は，HSD などのステロイド代謝酵菜の活性は無処置の ものに比べて低いといわれている。本実験においても， これらの報告と同様, 各種 HSD 活性の低下がみられた。 電顕的には, Kerr et al. (1979) が精巣停留処置を施し たラットのライディヒ細胞を観察しており, 滑面小胞体 は無処置のものよりもよく発達していると述へている が，血中テストステロン濃度は低いと報告している。こ の矛盾について彼らは, 精巣停留処置によって精子形成 を阻害された精細管は，ライディヒ細胞で合成されたテ ストステロンを急速に他のステロイドに転換するか，も しくは，ライディヒ細胞のテストステロン生合成を阻害 するステロイド代謝産物を生成している可能性があると 思考している。

本実験において，ブスルファンにより生殖細胞が欠如 した精巣では，七ルトリ細胞の HSD 活性は上昇したが, ライディヒ細胞の HSD 活性は明らかに低下した。今後, 血中テストステロン濃度やテストステロンの標的器官で ある副生殖器の重量を測定し, その結果に基づいてセル トリ細胞とライディヒ細胞に扔ける HSD 活性の変化の 機序を検討する予定である。

\section{References}

Aumüller G, Hartmann K, Giers U and Schenck B (1980) Fine structure of the Sertoli cells of the rat testis in experimental unilateral cryptorchidism. Int J Androl 3: 301-311.

Bloom W and Fawcett DW (1983) A Textbook of Histology, 10th ed., Saunders, Philadelphia, London and Toronto. pp 851-855, 882-883. 
Bollag W (1953) Der Einfluss von Myleran auf die Keimdrüsen von Ratten. Experientia 9: 268.

Dorrington JH, Fritz IB and Armstrong DT (1976) Site at which FSH regulates estradiol-17 $\beta$ biosynthesis in Sertoli cell preparations in culture. Molec Cell Endocr 6: 117-122.

Dorrington JH, Fritz IB and Armstrong DT (1978) Steroidogenesis by granulosa and Sertoli cells. Int J Androl Suppl 2: 53-56.

Hemsworth BN and Jackson H (1962) Effect of 'Busulphan' on the foetal gonad. Nature 195: 816-817.

Hemsworth BN and Jackson H (1963) Effect of busulphan on the developing gonad of the male rat. $J$ Reprod Fert 5: 187-194.

Kerr JB, Rich KA and De Krester DM (1979) Alterations of the fine structure and androgen secretion of the interstitial cells in the experimentally cryptorchid rat testis. Biol Reprod 20: 409-422.

Koizumi K and Ishida K (1985) Light and electron microscopic studies of testes in neonatal rats borne by busulphan-injected females. Jap J Fert Ster 30 : 269-275 (in Japanese).

Levy H, Deane HW and Rubin BL (1959) Visualization of steroid- $3 \beta$-ol-dehydrogenase activity in tissues of intact and hypophysectomized rats. Endocrinology 65: 932-943.

Niemi M and Ikonen M (1962) Cytochemistry of oxidative enzyme systems in the Leydig cells of the rat testis and their functional significance. Endocrinology 70: 167-174.

Samuels LT and Helmreich ML (1956) The influence of chorionic gonadotropin on the $3 \beta$-ol-dehydrogenase activity of testes and adrenals. Endocrinology 58: 435-442.

Schoen EJ (1964) Effect of local irradiation on testicular androgen biosynthesis. Endocrinology 75 : 56-65.

Tanaka M and Ishida K (1987) Histochemical demonstration of hydroxysteroid dehydrogenases in the rat testis with special reference to those in Sertoli cells. Jpn J Zootech Sci 58: 568-573 (in Japanese).

Tcholakian RK and Steinberger A (1978) Progesterone metabolism by cultured Sertoli cells. Endocrinology 103: 1335-1343.

Tence $M$ and Drosdowsky M (1976) Biosynthesis and metabolism of testosterone by Sertoli cell-enriched seminiferous tubules. Biochem Biophys Res Commun 73: 47-55.

Wiebe JP (1978) Isolated Sertoli cells from immature rats produce 20 $\alpha$-hydroxy-pregn-4-en-3-one from progesterone and $3 \beta, 20 \alpha$-dihydroxy- $5 \alpha$-pregnane from pregnenolone. Biochem Biophys Res Commun 84: 1003-1008.

Wiebe JP and Tilbe KS (1979) De novo synthesis of steroids (from acetate) by isolated rat Sertoli cells. Biochem Biophys Res Commun 89: 1107-1113.

\section{要 約}

ブスルファンにより生殖細胞を退行させた出生直後から生後50日までのラット精巣について, $\Delta^{5}-$ $3 \beta$-ヒドロキシステロイド脱水素酵素 $\left(\Delta^{5}-3 \beta-H S D\right), 20 \beta-H S D$ および $17 \beta-H S D$ の活性を組織化学 的に検出して無処置のものと比較した。これらの HSD 活性は，いずれのラットに扑てもセルトリ 細胞では生後20日から出現したが，生後40日以降はブスルファン投与ラットが無処置のものより強か った。ライディヒ細胞では，ブスルファン投与ラットの $\Delta^{5}-3 \beta-H S D$ (基質 ; DHA，プレグネノロン） 活性は無処置のものと変わらなかったが，その他の HSD 活性は常に弱かった。 